work on plants began with field observations on wild roses and willows, which led to researches in the cytogenetics of Rosa and its hybrids as well as of Salix, and the discovery that most British roses are of hybrid origin. In 1934 he commenced his work on the flora and fauna of the Hebrides. From these studies in systematics proceeded intensive studies in the biogeography of the area and in its Pleistocene and Holocene history and geography.

We have been informed that Prof. Harrison hopes to devote much time in future years to research. At present he remains working at King's College, holding for two years a College Research Fellowship, giving lecture courses on genetics and evolution, and supervising postgraduate researches in genetics. We hope that this last phase of his University career will prove as fruitful as all the varied earlier ones have been, and that many happy years are in store for him when he finally withdraws from the walls of his proud and grateful Alma Mater.

\section{Psychology at Aberdeen : Prof. Rex Knight}

THE most recent addition to the number of univer. sity chairs in psychology is at Aberdeen, where Mr. Rex Knight has been appointed to the Anderson professorship. Prof. Knight was born at Wilcannia, New South Wales, in 1903, and graduated from the University of Sydney in 1923 and the University of Cambridge in 1925. He was a member of the staff of the National Institute of Industrial Psychology during 1925-28, first as an investigator, then as assistant to the director, the late Dr. C. S. Myers, and co-editor of the Institute's journal. After a year as lecturer at the University of St. Andrews, he was appointed Anderson lecturer (later reader) in psychology at the University of Aberdeen in 1929. During the War, for three years he gave a weekly broadcast commentary for the Ministry of Information, together with numerous lectures for the Central Advisory Council for Education in the Forces in remote parts of Scotland. During 1943-45 he was attached to the War Office staff of the Directorate for Selection of Personnel. His book on "Intelligence and Intelligence Tests" is widely used, and he is well known for his advocacy, in 1932, of the strictly scientific approach to animal psychology (cf. his article in Nature of Nov. 9, 1932, on "The Explanation of Animal Behaviour"). But Prof. Knight's main interests are in dynamic and social psychology, the applications of psychology to everyday human problems, its relation to literature and the other arts, and the role of psychology as an ingredient in a general education.

\section{University of Glasgow}

The Department of Scientific and Industrial Research has offered to supply and erect for the Department of Natural Philosophy of the University of Glasgow a $300 \mathrm{MeV}$. synchrotron, and to make a capital grant of $£ 3,500$ towards the provision of a high-voltage generator. Dr.J. M. Hyslop has resigned his lecturership in mathematics in the University on his appointment to the chair of mathematics in the University of Witwatersrand. Dr. T. S. Stevens has resigned from the Department of Chemistry to become lecturer in organic chemistry in the University of Sheffield ; Drs. Stanley Alstead and R. A. Shanks have resigned from the Department of Materia Medica to become (respectively) medical consultant for the North of Scotland at Inverness and medieal registrar at Yorkhill Hospital for Children, Glasgow. Messrs. C. E. Bond, R. Lambert Hurt and A.J. Webster have been appointed assistants in the Department of Anatomy, and Mr. John Higginson an assistant in bacteriology.

\section{Mechanical Recording of Information}

THE system used at the Royal Cancer Hospital to record information numerically about cancer patients so that it can be transferred to a punched card and sorted mechanically is described by D. W. Smithers, K. M. H. Branson and H. O. Hartley in a pamphlet which includes also the instruction book and code book in use (from the Royal Cancer Hospital). This information should be of general interest to the medical research worker and to others who are considering the use of punched cards for bibliographic purposes or statistical analysis. The essential features of the system are the compilation of a special record card from notes on the patient, the information on the card being such that it can be expressed in numerical form and is suitable for rapid analysis by mechanical means. Filling in this card is the only extra clerical work required of the medical man, usually a registrar, beyond his usual duties of keeping accurate notes. The time required for coding and preparing the card for punching is greater, but this work can be carried out by a specially trained clerk. The special record cards remain the property of the hospital and are filed there. Most of the information on these cards can be transferred to a Hollerith punched card by a clerk trained for the purpose and employed by the hospital, or if no such clerk is available they may be sent for punching to the British Tabulating Machine Co., Ltd. As analysis of both standard data and special hospital data is made mechanically, information obtained from the cards can be supplied either to a central organisation, an individual hospital or to any clinician concerned.

The Royal Cancer Hospital and the group of hospitals with which it co-operates are giving the system a preliminary trial for all cancer patients coming under their care from January 1, 1945.

\section{Abstracts of World Medical Literature}

Two new monthly medical abstracting journals, Abstracts of World Medicine and Abstracts of World Surgery, Obstetrics and Gynoecology, have been published by the British Medical Association. The first (January) issues have now appeared, and even a glance through the pages shows that Dr. Hugh Clegg, editor of the British Medical Journal, under whose general direction they are being issued, and Dr. G. M. Findlay, who edits them with the assistance of Dr. S. S. B. Gilder and a panel of advisers, are to be congratulated on both the planning and the execution of the considerable task which they have undertaken. The foreword to both these issues traces the history of recent medical abstracting work, from the Medical Research Council's publication during the First World War, of information derived from medical literature then appearing, to the similar service begun during the Second World War and continued in the form of the Bulletin of War Medicine. The success of the latter encouraged the British Medical Association to continue an abstracting service when this bulletin ceased publication in 1946, and the two new journals are the result - They give, over a remarkably wide range, abstracts of articles selected from more than 